\title{
CHEMICAL ATOMIC ARRANGEMENT OF AMORPHOUS ALLOYS
}

\author{
アモルファス合金の化学的原子配列
}

\section{Toshiharu FUKUNAGA}

\author{
Department of Crystalline Materials Science, Nagoya University \\ Furo-cho, Chikusa-ku, Nagoya, 464-01, Japan. \\ Tel:052-7.89-4462, Fax:052-789-3724
}

( Received 27, June 1994 Accepted 21, September 1994)

\section{ABSTRACT}

\begin{abstract}
Amorphous structure has been investigated from not only the topological viewpoint but also the chemical one. Especially, the neutron diffraction allows one to observe directly the concentrationconcentration correlation functions of the neutron zero scattering amorphous alloys. The chemical short-range order (CSRO) of $\mathrm{Ti}-\mathrm{Cu}$ and $\mathrm{Ti}-\mathrm{Ni}$ neutron zero scattering amorphous alloys differs from each other, even though $\mathrm{Ni}$, being located next to $\mathrm{Cu}$ in the Periodic Table, has an atomic size which is almost the same as that of $\mathrm{Cu}$. The CSRO of Ti-Ni-Cu ternary neutron zero-scattering amorphous alloys is found to increase rapidly with increasing $\mathrm{Ni}$ content. The results indicate that an increase of the CSRO by alloying with $\mathrm{Ni}$ element is ascribed to the stronger affinity of a $\mathrm{Ni}$ atom with a $\mathrm{Ti}$ atom than that of a $\mathrm{Cu}$ atom. Moreover, the CSRO strongly affects with the thermal properties, i.e., the crystallization temperature and the enthalpy of crystallization.
\end{abstract}

Key words : amorphous alloy, neutron diffraction, structure, chemical short range order

\section{1. 緒 言}

アモルファス合金は結晶と異なり構造学的に長 距離範囲で規則的な配列を持たないもの、すなわ ち乱れた状態にあるものと認識されている。この 見方は幾何学的な観点からのもので、通常原子の 配列はこの幾何学的観点から観察され、議論され ることになる。ところが構造はもう一つの視点か ら眺める必要がある。それは化学的構造1-4である。 化学的な原子配列という言葉はあまり耳慣れない かもしれない。この言葉は 1 種類のみの原子から なるアモルファス、例えばアモルファスシリコン にはこの言葉は無いのである。この言葉が有効に なるのは 2 元系以上すなわち 2 種類以上の原子が
混ざり会っている場合のみである。これで想像が つくであろう。ここで用いる化学的原子配列とは お互い異なる種類の原子がどのような分布で混ざ りあうかということを意味している。すなわち、 ある種類の原子の隣には同じ種類の原子が位置し 易いのか、それとも異なる種類の原子が位置し易 いのか、そしてその異なる種類の原子の中でもど のような種類の原子が隣に位置し易いのかという ことである。この問題は種類の異なる原子同士の 親和性(affinity)と関係しており、アモルファスを 研究する上で非常に重要である。よって、本文で はその化学的な原子配列という観点からアモルフ アス構造を眺めていくことにする。 


\section{2. 構造の観察}

アモルファス合金の構造を記述する方法として、 通常Faber-Ziman ${ }^{5}$ にって定義された構造因子 $\mathrm{S}^{\mathrm{FZ}}(\mathrm{Q})$ が用いられる。この $\mathrm{S}^{\mathrm{FZ}}(\mathrm{Q})$ は $\mathrm{A}-\mathrm{B} 2$ 元系のア モルファス合金を例にとると構成成分の $\mathrm{A}, \mathrm{B}$ 原子 同士の相関、すなわちA-A、A-BそしてB-B相関を 表す各部分構造因子の重み付き和で表される。

$$
\begin{aligned}
S^{\mathrm{FZ}}(\mathrm{Q})=\frac{1}{\langle\mathrm{~b}\rangle^{2}} & \left\{\mathrm{C}_{\mathrm{A}}^{2} \mathrm{~b}_{\mathrm{A}}^{2} \mathrm{~S}_{\mathrm{AA}}(\mathrm{Q})\right. \\
& \left.+2 \mathrm{C}_{\mathrm{A}} \mathrm{C}_{\mathrm{B}} \mathrm{b}_{\mathrm{A}} \mathrm{b}_{\mathrm{B}} \mathrm{S}_{\mathrm{AB}}(\mathrm{Q})+\mathrm{C}_{\mathrm{B}}^{2} \mathrm{~b}_{\mathrm{B}}^{2} \mathrm{~S}_{\mathrm{BB}}(\mathrm{Q})\right\}
\end{aligned}
$$

ここで $\mathrm{b}_{\mathrm{A}}\left(\mathrm{b}_{\mathrm{B}}\right)$ そして $\mathrm{C}_{\mathrm{A}}\left(\mathrm{C}_{\mathrm{B}}\right)$ は $\mathrm{A}(\mathrm{B})$ 原子の干渉性散 乱振幅ならびに濃度であり、そして $<\mathrm{b}\rangle=\mathrm{C}_{\mathrm{A}} \mathrm{b}_{\mathrm{A}}+\mathrm{C}_{\mathrm{B}} \mathrm{b}_{\mathrm{B}}$ である。

もう一つよく用いられる構造因子としては Bhatia-Thornton ${ }^{1}$ にっって定義された $\mathrm{S}^{\mathrm{BT}}(\mathrm{Q})$ である。 この $\mathrm{S}^{\mathrm{BT}}(\mathrm{Q})$ は密度摇らぎを表す部分構造因子 $\mathrm{S}_{\mathrm{NN}}(\mathrm{Q})$ と濃度摇らぎを表す部分構造因子 $\mathrm{Scc}(\mathrm{Q})$ 、 そしてその交差項である密度-濃度相関を表す部 分構造因子 SNC(Q)の重み付き和で表される。

$$
\begin{aligned}
\mathrm{S}^{\mathrm{BT}}(\mathrm{Q})=\frac{1}{\left\langle\mathrm{~b}^{2}\right\rangle} & \left\{\langle\mathrm{b}\rangle^{2} \mathrm{~S}_{\mathrm{NN}}(\mathrm{Q})\right. \\
& \left.+2\langle\mathrm{~b}\rangle \Delta \mathrm{b} \mathrm{S}_{\mathrm{NC}}(\mathrm{Q})+\Delta \mathrm{b}^{2} \mathrm{~S}_{\mathrm{CC}}(\mathrm{Q})\right\}
\end{aligned}
$$

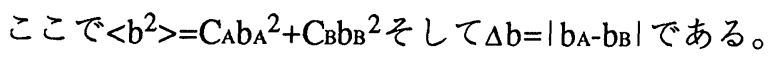
これらFaber-Ziman型の部分構造因子（ $\mathrm{S}_{\mathrm{AA}}(\mathrm{Q})$, $\mathrm{S}_{\mathrm{AB}}(\mathrm{Q}), \mathrm{S}_{\mathrm{BB}}(\mathrm{Q})$ ）と Bathia-Thornton型部分構造因子 $\left(\mathrm{S}_{\mathrm{NN}}(\mathrm{Q}), \mathrm{S}_{\mathrm{Nc}}(\mathrm{Q}), \operatorname{Scc}(\mathrm{Q})\right)$ は異なった定義によって 導出されるが、お互い次式のように関連づけられ るものである。

$$
\left.\begin{array}{c}
S_{A A}(Q)=\left\{C_{A}^{2} S_{N N}(Q)+2 C_{A} S_{N C}(Q)+S_{C C}(Q)\right. \\
\left.-C_{A} C_{B}\right\} / C_{A}^{2} \\
S_{A B}(Q)=\left\{C_{A} C_{B} S_{N N}(Q)-\left(C_{B}-C_{A}\right) S_{N C}(Q)\right. \\
-S_{C C}(Q)+C_{A} C_{B} / C_{A} C_{B} \\
S_{B B}(Q)=\left\{C_{A}^{2} S_{N N}(Q)-2 C_{B} S_{N C}(Q)+S_{C C}(Q)\right. \\
\left.-C_{A} C_{B}\right\} / C_{B}^{2}
\end{array}\right\}
$$

構造因子は逆空間での情報であるが、フーリエ 変換によって実空間上の原子分布関数に変換され る。Faber-Ziman型の部分 2 体分布関数は次式で結 ばれる。

$$
\mathrm{g}_{\mathrm{ij}}(\mathrm{r})=1+\frac{1}{2 \pi^{2} \mathrm{r} \rho_{0}} \int_{0}^{\infty} \mathrm{Q}\left\{\mathrm{S}_{\mathrm{ij}}(\mathrm{Q})-1\right\} \sin \mathrm{Q} \cdot \mathrm{rdQ}
$$

他方、Bhatia-Thornton型の部分分布関数は次式で 定義される。

$$
\left.\begin{array}{l}
\mathrm{G}_{\mathrm{NN}}(\mathrm{r})=\frac{1}{2 \pi} \int_{0}^{\infty} \mathrm{Q}\left(\mathrm{S}_{\mathrm{NN}}(\mathrm{Q})-1\right) \sin \mathrm{Q} \cdot \mathrm{rdQ} \\
\mathrm{G}_{\mathrm{NC}}(\mathrm{r})=\frac{1}{2 \pi} \int_{0}^{\infty} \mathrm{QS} \mathrm{S}_{\mathrm{NC}}(\mathrm{Q}) \sin \mathrm{Q} \cdot \mathrm{rdQ} \\
\mathrm{G}_{\mathrm{CC}}(\mathrm{r})=\frac{1}{2 \pi} \int_{0}^{\infty} \mathrm{Q}\left\{\frac{\mathrm{S}_{\mathrm{CC}}(\mathrm{Q})}{\mathrm{C}_{\mathrm{A}} \mathrm{C}_{\mathrm{B}}}-1\right\} \sin \mathrm{Q} \cdot \mathrm{rdQ}
\end{array}\right\}
$$

本解説ではBhatia-Thorntonによって定義された 構造因子ならびに原子分布関数を用いてアモルフ アス合金の化学的原子配列を議論することにする。 特にこの方法を通して化学的原子配列を観察する ために中性子零散乱アモルファス合金を用いる。 この中性子零散乱アモルファス合金とは中性子に 対する平均の干渉性核散乱振幅が零になる合金を 意味している。すなわち、Bhatia-Thorn ton型 $\mathrm{S}^{\mathrm{BT}}(\mathrm{Q})$ において る。この時、 $\mathrm{S}_{\mathrm{NN}}(\mathrm{Q})$ 抢よび $\mathrm{S}_{\mathrm{Nc}}(\mathrm{Q})$ の重み因子は零 になるので、Scc(Q)のみすなわち原子レベルの濃 度摇らぎ分布関数のみを直接観察することが出来 るのである。なお、ここで示す中性子零散乱アモ ルファス合金は液体急冷(LQ) もしくはメカニカル アロイング(MA)法によって作製されたものである。

\section{2元系アモルファス合金}

アモルファス合金の化学的短範囲構造はその系 によって大きく異なっている。とくに金属－非金 属系と金属一金属系に分類すると、金属一非金属 系では化学的短範囲規則性の観点からみてその規 則性は非常に高く6、しかも構成原子の種類にあ 
まり依存していないことが報告されている。これ は金属と非金属の間の化学的結合力が大きいこと に起因しているものと考えられている。ところが、 金属一金属系においては同じアモルファス状態に おいてもその金属の種類によってはその化学的原 子配列が大きく異なっている。Fig. 1ならびに Fig.2はTi70Cu30ならびにTi76Ni24中性子零散乱ア モルファス合金7-9の濃度摇らぎ部分分布関数 $\mathrm{RCF}(\mathrm{r})=\mathrm{rGcc}(\mathrm{r})$ を示している。これらの中性子零 散乱アモルファス合金はTi原子が中性子に対して

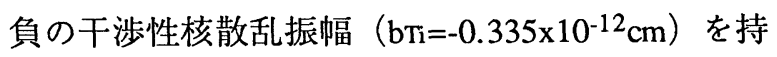
つことを利用して、 $\mathrm{Cu}$ 原子 $\left(\mathrm{bCu}=0.7718 \times 10^{-12} \mathrm{~cm}\right)$

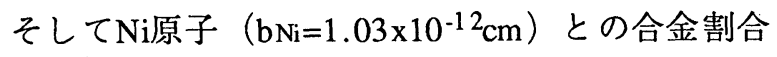
を調整することにより平均の散乱振幅く $\mathrm{b}>$ を零に して作製している。これらのアモルファス合金の 化学的構造は $\mathrm{Ni} ら ら ひ ゙ に \mathrm{Cu}$ 原子サイズがほほ同 じで、しかも周期表で隣合わせに位置するにもか かわらず大きく異なっている。すなわち、 Ti70Cu30アモルファス合金ではRCF(r)の最隣接原

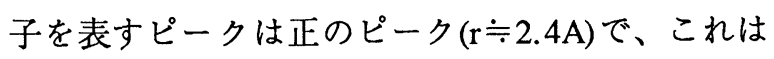
同種原子すなわち $\mathrm{Cu}$ 原子のまわりに $\mathrm{Cu}$ 原子が最 隣接位置に存在していることを表している。それ に対し、Ti76Ni24アモルファス合金のRCF(r)の最 初の $\mathrm{r}=2.54 \mathrm{~A}$ 位置にあるピークは負であり、これ は異種金属原子同士すなわち $\mathrm{Ni}$ 原子のまわりには Ti原子が集まっていることを示しているのである。 このr=2.54Aに位置するの第 1 近接 Ni-Ti対がその 合金の近傍組成に存在する Ti2 $\mathrm{Ni}$ 化合物結晶にも 存在していることから、その化学的短範囲構造は 類似していること示唆している。ところが、 Ti70Cu30アモルファス合金のRCF(r)とTi2Cu化合物 結晶の原子分布の比較ではTi-Ni系で見られたよう な類似は観察されず、Ti-Ni系とTi-Cu系アモルフ アス合金の化学的原子配列は本質的に異なってい るものと考えられるのである。

この化学的原子分布の形態の定量的な評価は、 Warren ${ }^{10}$ によって定義された化学的短範囲規則度 パラメータ $(\alpha)$ で行なわれる。

$$
\alpha=\frac{1}{\mathrm{Z}} \int_{\Delta \mathrm{r}} \mathrm{rG}(\mathrm{r}) \mathrm{dr}
$$

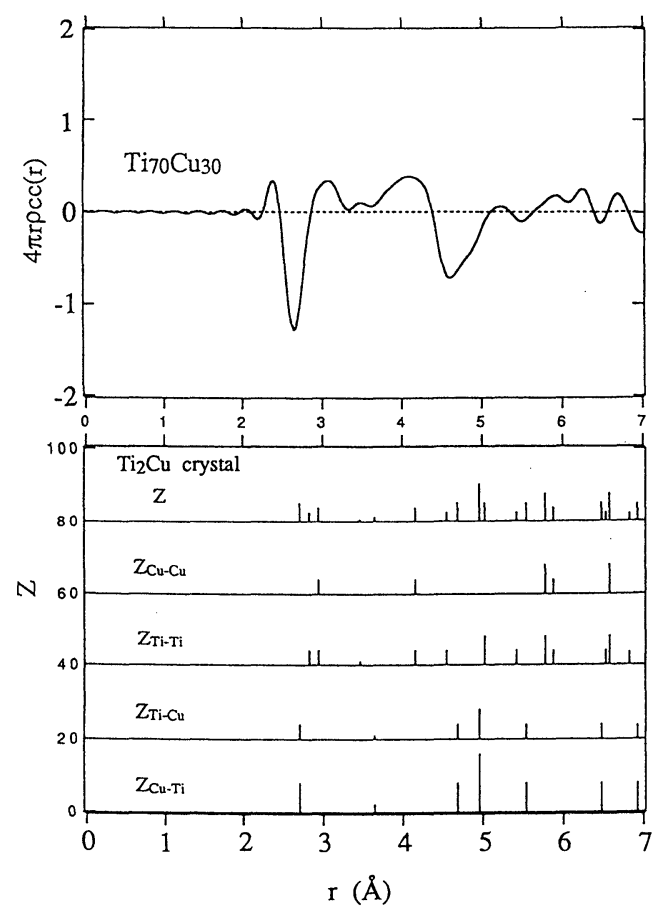

Fig. 1. Reduced concentration correlation function $\mathrm{Gcc}(\mathrm{r})=4 \pi \mathrm{r} \rho \mathrm{cc}(\mathrm{r})$ for the $\mathrm{Ti70 \textrm {Cu } 3 0}$ neutron zero scattering amorphous alloys prepared by MA, and $\mathrm{Ti}-\mathrm{Ti}, \mathrm{Cu}-\mathrm{Ti}$ and $\mathrm{Cu}-\mathrm{Cu}$ correlations in $\mathrm{Ti} 2 \mathrm{Cu}$ crystalline compound.

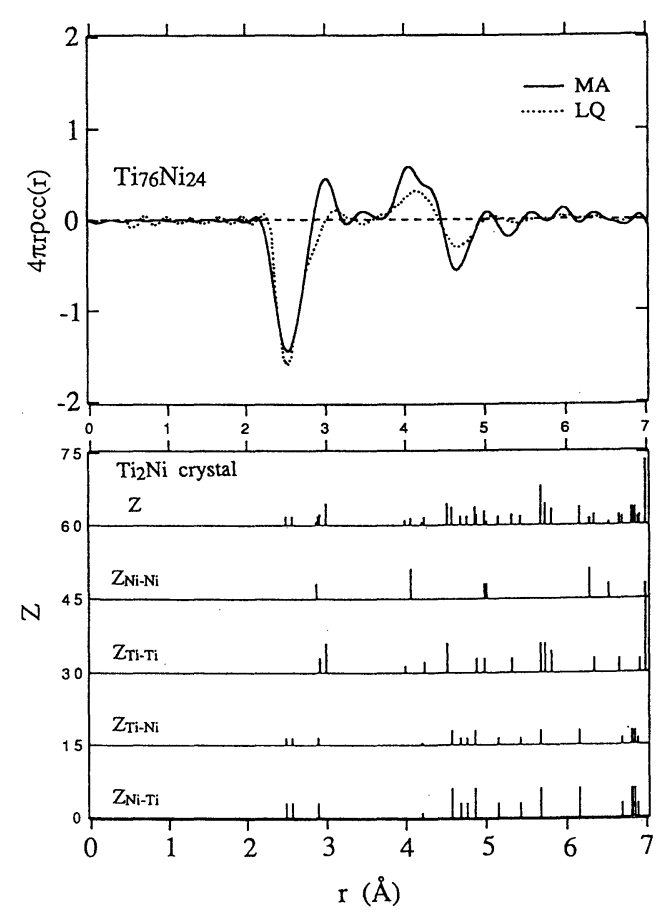

Fig. 2. Reduced concentration correlation function $\operatorname{Gcc}(r)=4 \pi r \rho c c(r)$ for the $\mathrm{Ti} 76 \mathrm{Ni} 24$ neutron zero scattering amorphous alloys prepared by MA and $\mathrm{LQ}$, and $\mathrm{Ti}-\mathrm{Ti}, \mathrm{Ni}-\mathrm{Ti}$ and $\mathrm{Ni}-\mathrm{Ni}$ correlations in Ti2Ni crystalline compound. 
ここで、Zはある原子のまわりに存在する第 1 隣 接原子数であり、 $\Delta \mathrm{r}$ は第 1 隣接原子の分布幅を表 している。計算される $\alpha$ の值が $0<\alpha<1$ の場合は同 種原子同士が集まりやすく、 $\alpha=0$ の場合は統計的 に無秩序な分布を表す、そして- $\mathrm{CA} / \mathrm{CB}<\alpha<0$ の場合 は異種原子同士が集まりやすいことを表している。 ここで- $\mathrm{CA} / \mathrm{CB}(\mathrm{CA}<\mathrm{CB})$ はある原子の回りには完全 に異なった種類の原子が集まった状態すなわち完 全な化学的規則性を持った状態を表している。こ の方法でTi-Ni系とTi-Cu系アモルファス合金の化 学的短範囲規則度を評価すると Ti70Cu30アモルフ アス合金ではその $\alpha$ の值は-0.029、そしてTi76 $\mathrm{Ni} 24$ アモルファス合金のその值は-0.091となる。これ らの值はTi76Ni24アモルファス合金の化学的短範 囲規則性がTi70Cu30アモルファス合金と比べて良 い、すなわち最隣接位置に異種原子同士が集まり やすいことが示しているのである。

このような化学的短範囲規則構造が組成を変え ても存在するどうかは興味ある問題である。Fig. 3 に 3 種類のTi-Ni系の中性子零散乱アモルファス合 金の $\mathrm{Gcc}(\mathrm{r})^{8}$ を示している。3 種類の中性子零散乱 アモルファス合金はTi原子、天然の Ni原子そして 同位体の ${ }^{60} \mathrm{Ni} （ \mathrm{~b}^{6} 00 \mathrm{Ni}=0.28 \times 10^{-12} \mathrm{~cm}$ ）を組み合せて 作製している。 $\mathrm{r}=2.54 \mathrm{~A}$ に位置する負のピークの 面積から $\mathrm{Ni}$ 原子に近接する $\mathrm{Ti}$ 原子の配位数を計算 するとFig. 48,9で示すようになる。アモルファス 合金の Ni原子まわりのTi原子の配位数は無秩序配 列の場合のそれょりも多く、むしろ Ti2 Niおよび TiNi化合物結晶の值を結ぶ直線に良くのっている。 これらの実験事実はTi-Ni系のアモルファス合金の 原子配列が化学的に無秩序ではなく、対応する化 合物の化学的短範囲秩序と類似していることを示 している。

\section{3 元系アモルファス合金}

前述したようにTi-Cu系ならびにTi-Ni系のアモ ルファス合金の化学的構造は大きく異なっており、 この要因はTiと Ni原子そしてTiと Cu原子同士の親 和性の違いと考えられている。もしNiとCu原子が 共に存在する $\mathrm{Ti}-\mathrm{Ni}-\mathrm{Cu}$ 系アモルファス合金におけ る化学的構造はそしてその規則度はどのようにな
るであろうか。これは多元系のアモルファス合金 の構造の情報を得ることができるばかりではなく、 アモルファス合金の特異な性質の発現の起源や熱 的安定性の要因を知る上でも重要なことと考えら れる。

Fig.5に(Ti76Ni24)x(Ti70Cu30)1-x中性子零散乱アモ ルファス合金の中性子回折によって観察された $\mathrm{SCC}(\mathrm{Q})$ を示す11,12。またFig.6はフーリエ変換によ

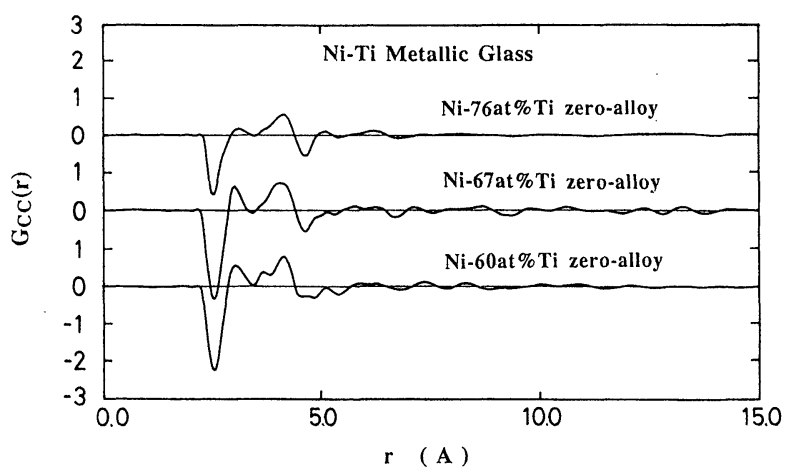

Fig. 3. Reduced concentration correlation functions $\operatorname{Gcc}(r)=4 \pi r \rho c c(r)$ for the Ti76Ni24, Ti67Ni33 and Ti60Ni40 neutron zero scattering amorphous alloys

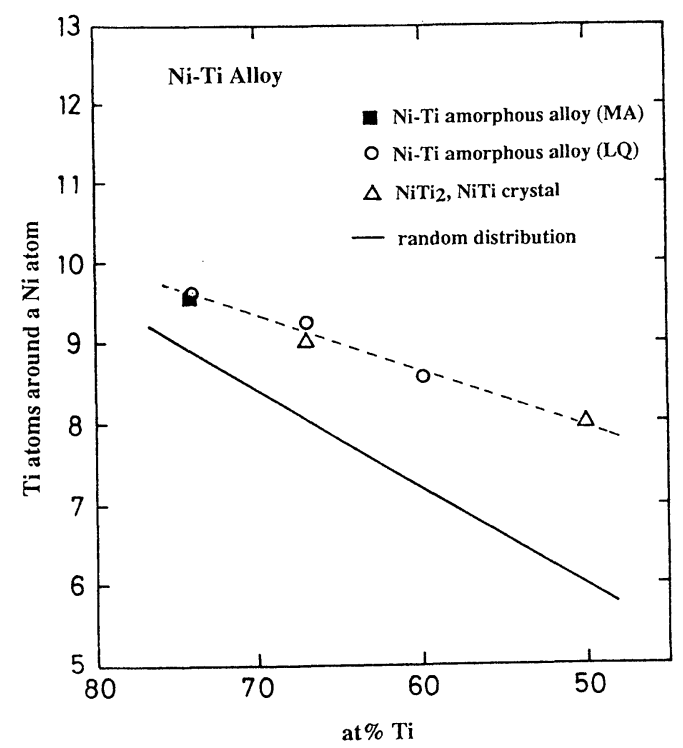

Fig. 4. Coordination numbers of $\mathrm{Ti}$ atoms around a $\mathrm{Ni}$ atom in $\mathrm{Ni}-\mathrm{Ti}$ amorphous alloys prepared by $\mathrm{MA}$ and LQ, and crystalline $\mathrm{Ti} 2 \mathrm{Ni}$ and $\mathrm{TiNi}$ compound. The solid line gives the coordination number of $\mathrm{Ti}$ atoms around a $\mathrm{Ni}$ atom in the case of a statistically random distribution under the total coordination number of 12 atoms. 


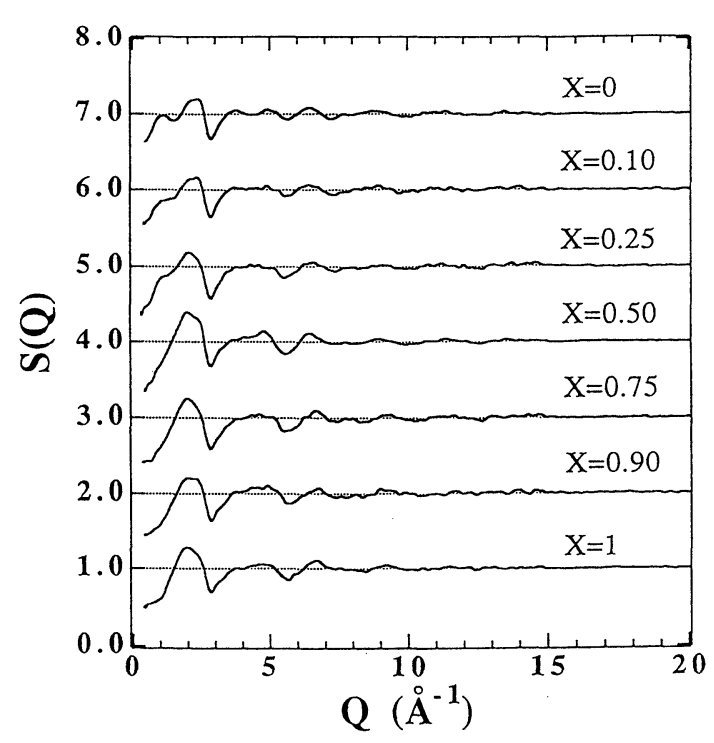

Fig. 5. Structure factors for the (Ti76Ni24)X(Ti70Cu30)1-X (X=0, 0.1, 0.25, 0.5, $0.75,0.9,1)$ amorphous alloys

って得られた RCF $(\mathrm{r}) を$ 示している。前述したよう にTi70Cu30アモルファス合金のRCF(r)はr〜2.4A に正のピークそして $\mathrm{r} \sim 2.7 \AA$ に負のピークが観察 される。ところがTi76Ni24アモルファス合金の $\mathrm{RCF}(\mathrm{r})$ は最初 $\mathrm{r}=2.54 \AA$ に負のピークが観察される。 正のピークは同種金属原子同士、また負のピーク は異種金属原子同士の相関を表していることから、 Ti70Cu30アモルファス合金では最隣接原子位置に $\mathrm{Cu}-\mathrm{Cu}$ 相関の同種原子が位置していることを示し ているのである。これに対して、Ti76Ni24アモル ファス合金では最初に負のピークが存在すること から、Ti-Ni相関である異種原子が位置しているこ ととなる。そのRCF(r)から(Ti76Ni24)x(Ti70Cu30)1-x アモルファス合金の構造の組成依存性を眺めてみ ると、 $\mathrm{Cu}$ 原子が $\mathrm{Ni}$ 原子に置き変わるにつれて最隣 接原子位置にみられた同種原子相関の正のピーク はなくなり、50\%置換にいたるとその痕跡は全く 見られなくなっている。これは $\mathrm{Cu}$ 原子の $\mathrm{Ni}$ 原子に よる置換により、その短範团構造が大きく変化し ていることを意味している。

Fig.7に(Ti76Ni24)x(Ti70Cu30)1-xアモルファス合 金における $\alpha$ 值の組成依存性 11,12 を示している。 $\mathrm{Ti70} \mathrm{Cu} 30$ アモルファス合金の $\alpha$ 值は非常に零に近 い負值であり、Ti76Ni24アモルファス合金のそれ

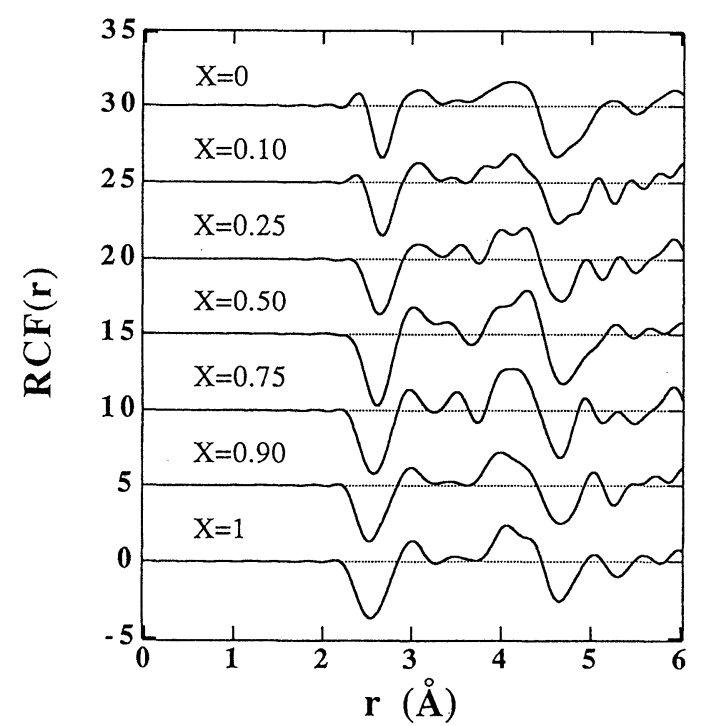

Fig. 6. Radial concentration functions for the (Ti76Ni24)X(Ti70Cu30)1-X (X=0, 0.1, 0.25, 0.5, $0.75,0.9,1)$ amorphous alloys.

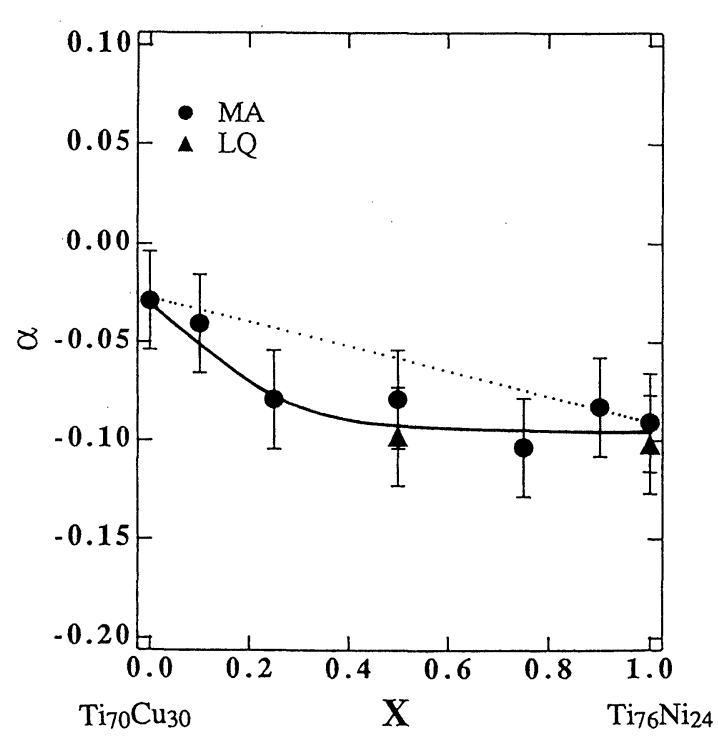

Fig. 7. Warren chemical short range order parameter a as a function of $X$ for the pseudobinary $(\mathrm{Ni} 24 \mathrm{XCu} 30(1-\mathrm{X})) \mathrm{Ti} 70+6 \mathrm{X}=\mathrm{TM} 30-6 \mathrm{XTi70}+6 \mathrm{X}$ $(\mathrm{TM}=\mathrm{Ni}$ and $\mathrm{Cu})(\mathrm{X}=0,0.1,0.25,0.5,0.75,0.9$, 1) amorphous alloys

はTi70Cu30アモルファス合金のそれと比べるとよ り大きな負の值となっている。その間の $\alpha$ 值の組 成依存性を見てみると、全組成において実験から 得られた $\alpha$ 值はTi76Ni24と Ti70Cu30アモルファス合 金の平均の $\alpha$ 值（点線）ょりもより負の方向に shiftしている。少量のNi原子が $\mathrm{Cu}$ 原子と置き变る ことによって 值は急激に負の方向に变化した後、 


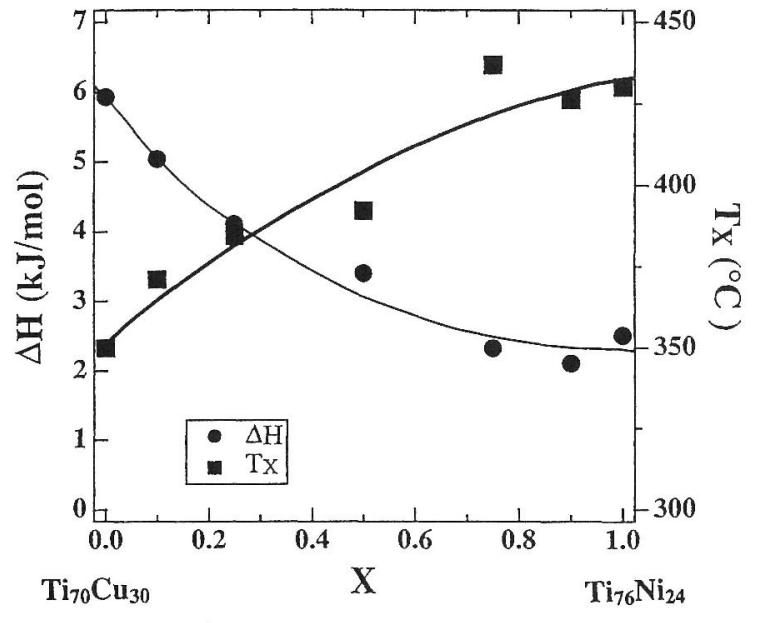

Fig. 8. The crystallization temperature and the enthalpy of crystallization for the (Ti76Ni24)X(Ti70Cu30)1-X (X=0,0.1, 0.25, 0.5, $0.75,0.9,1)$ amorphous alloys

その割合が50at\%をこえるとTi76Ni24アモルファス 合金とほほ同じ值を示すようになる。このように 化学的規則性はNiの添加によってTi76Ni24アモル ファス合金と同じ程度となるという結果はNi原子 がCu原子の周りの環境を変え、系全体の化学的短 範囲規則性を良くしているものと解釈される。

次に、化学的規則性と熱的安定性の関係を眺め てみる。Fig.8に示差熱分析装置(DSC)によって測 定されたアモルファスから結晶への変化する温度 と、その時生じる発熱量を示している12。

(Ti76Ni24)x(Ti70Cu30)1-xアモルファス合金の熱的性 質(Fig. 8) と化学的規則度(Fig.7)の組成依存性を比 較すると、結晶化温度は化学的規則性の高い Ti76Ni24アモルファス合金の方が高いが、結晶化 にともなう発熱量はTi70Cu30アモルファス合金の それに比べて少ないことが明らかとなる。これは 化学的結合の強い方が強固にそのアモルファスの 形態を保とうとするため結晶化が遅れ、そしてそ の化学的規則性が結唱のそれと類似しているため 結晶化にともなう原子の動きは少なく、それ故に 原子の動きと関連する結晶化発熱量は少なくなる ものと考えられるのである。また逆に、Ti70Cu30 アモルファス合金のように化学的結合力が弱く化 学的に無秩序配列に近いと熱的に不安定であるた め比較的低い温度で結晶化が生じ、化学的に規則
性の高い結晶相へ変化するためには原子を移動さ せ、異種原子の位置関係を大きく変化させる必要 があるためその発熱量は大きくなるものと考えら れるのである。

\section{5. 結 言}

Ti-Ni系ならびにTi-Cu系アモルファス合金を用 いて化学的短範团構造についてこれまでのデー夕 を基にしてまとめてみた。化学的短範囲構造は幾 何学的短範囲構造に対して異なった側面からアモ ルファス構造を眺めるということで非常に有用で あると考えられる。特に、化学的原子配列は異種 原子間の相関を明確にすることが出来るので、そ のアモルファス合金がかもしだす特異な性質やそ の熱的安定性と関連づけることが可能になると考 えられる。その中でも化学的秩序性と熱的安定性 については本文中で示したように密接な関係が明 らかにされつつある。今後このように構造と物性 との関係を明らかにすることは非常に重要であり、 是非行なわなければならない研究であると考えて いる。

References

${ }^{2}$ A.B.Bhhatia and D.E.Thornton, Phys.Rev. B2,3004(1970).

${ }_{3}^{2}$ C.N.J.Wagner,J.Non-Cryst.Solids,42,3(1980).

${ }^{3}$ M.Sakata,N.Cowlam and H.A.Davies,Proc. 4th Int.Conf.on Rapidly Quenched Metals (Sendai,1981)p.327.

${ }^{4}$ T.Fukunaga, K.Kai,M.Naka,N.Watanabe and K.Suzuki,Proc.4th Int.Conf. on Rapidly Quenched Metals(Sendai,1981)p.347.

${ }^{5}$ T.E.Fabar and J.M.Ziman,Phil.Mag.,11,153(1965).

${ }^{6}$ G.S.Cargill III and F.Spaepen,J.NonCryst.Solids,43,91(1981).

${ }^{7}$ T.Fukunaga, N.Watanabe and K.Suzuki,J.NonCryst.Solids 61\&62,343(1984).

${ }^{8}$ T.Fukunaga,N.Hayashi,K.Kai, N.Watanabe and K.Suzuki,Physica 120B,352(1983).

${ }^{9}$ T.Fukunaga, M.Misawa, K. Suzuki and U.Mizutani,Mat.Sci.Forum,88-90,325(1992).

${ }^{10}$ B.E.Warren, B. L.Aberbach and B.W.Roberts,J.Appl.Phys.,22, 1493(1951).

${ }^{11}$ T.Fukunaga,K.Okasaka and U.Mizutani,J.Non-Cryst. Solids, 156-158,120(1993).

${ }^{12} \mathrm{~T}$. F u k u nag a, K. O k a s a k a a n d U.Mizutani,J.S.P.M.40,307(1993).

著者紹介 福永利晴

1973年 名古屋工業大学卒、1979年東北 大学大学院工学研究科博士課程終了。 現名古屋大学工学部助教授。

専攻、材料物性、特にアモルファス金属、 アモルファス半導体そして酸化物ガラスと いったランダム構造物質の構造や、物性の 研究。 